\title{
The Evolutionary History of Glycosyltransferase Genes
}

\author{
糖転移酵素遺伝子の進化史
}

\author{
Kaneko, Mika ${ }^{1,2,3}$; Nishihara, Shoko ${ }^{2}$; Narimatsu, Hisashi' ${ }^{2}$, and Saitou, Naruya ${ }^{3}$ \\ 'Department of Forensic Medicine, Yamagata University School of Medicine, 2-2-2 Iida-Nishi, Yamagata, 990-9585, Japan \\ FAX: 81-23-628-5273, E-mail: mkaneko@med.id.yamagata-u.ac.jp \\ ${ }^{2}$ Division of Cell Biology, Institute of Life Science, Soka University, 1-236 Tangi, Hachioji, Tokyo 192-8577, Japan \\ ${ }^{3}$ Laboratory of Evolutionary Genetics, National Institute of Genetics, 1111 Yata, Mishima, 411-8540, Japan
}

Key Words : evolutionary rate, gene duplication, genome duplication, glycosyltransferase, molecular evolutionary analyses

\begin{abstract}
In the past few years, rapid advances have been made in sequencing the genomic DNA of human, Caenorhabditis elegans, and so on. As a result, a large number of novel glycosyltransferase genes have been discovered from those genome sequences. How did they increase their family members during the genome evolution? To presume the evolutionary pathway of glycosyltransferases, we have used the molecular evolutionary analysis (1). In that study, we conducted molecular evolutionary analyses on 55 glycosyltransferase genes and mainly discussed about glycosyltransferase genes for $\mathrm{N}$ - or O-glycan synthesis. The phylogenetic trees showed the glycosyltransferase genes increased their numbers through gene duplications. We also estimated the divergence time of each branch root and suggested that the glycosyltransferase genes increased their numbers through gene duplications and genome duplications. Comparison of evolutionary rates indicated that the glycosyltransferases tend to evolve more slowly than other genes, and the evolutionary rates changed within each of the glycosyltransferase gene families. These results indicate that the increase in glycosyltransferase genes allows the amino acid change and permits, the creation of the variety of specific activity of the enzyme. Here, we would like to introduce the essence of the evolutionary history of glycosyltransferase genes.
\end{abstract}

\section{A. Construction of Phylogenetic Tree and Estimation of Di- vergence Time of Phylogenetic Trees}

All carbohydrate chains are synthesized through the coordinated reaction of glycosyltransferases through a step-by-step elongation. Glycosyltransferases catalyze the transfer of sugar residues from nucleotide sugars (donor) to a growing carbohydrate chain (acceptor) and are usually very specific for both donor and acceptor substrates. Glycosyltransferases can be grouped into functional families based on their sequence similarities, which reflect their enzymatic character: donor specificity, acceptor specificity, and linkage specificity between donor and
要 約

近年、ヒトや線虫などのゲノム計画が急速に発展してきて いる。その結果、これらのゲノム配列の中からたくさんの新規 糖転移酵素遺伝子が見いだされるようになった。一体どのよう にして糖転移酵素は、進化の過程でその遺伝子ファミリーの構 成員を増やしてきたのだろうか? 糖転移酵素遺伝子の進化の道 筋を辿る目的で、分子進化学的な手法を用いて解析を行った (1)。我々は55種類の糖転移䤉素遺伝子を使って解析を行い、主 にN-glycan と O-glycanを合成する糖転移酥素に関して論じた。 系統樹の解析によって、糖転移酵素遺伝子が遺伝子重複を通し てその遺伝子数を増やしていったことが明らかになった。更 に、各遺伝子の分岐年代を推定したところ、糖転移酵素遺伝子 が遺伝子重複とゲノム重複でその遺伝子数を増やしたことが、 さらに、支持された。また、進化速度を比較したところ、糖転 移酵素遺伝子は他の遺伝子より進化速度が遅い傾向にあり、遺 伝子ファミリー内でばらつきが認められた。これらの結果か ら、糖転移酵素遺伝子が遺伝子重複やゲノム重複で遺伝子数を 増やしたことにより、機能的制約がゆるみ、アミノ酸変異が蓄 積して酵素活性に多様性をもたらされた、と推察される。本稿 では、これらの解析を通して得られた「糖転移䤉素遺伝子の進 化史」のエッセンスを述べる。

\section{A. 系統樹の作成と分岐年代の推定}

糖鎖は糖転移酵素によって逐次伸長・合成される。糖転移 酵素は糖ヌクレオチド(donor、供与体)から糖を伸長していく糖 鎖(acceptor、受容体)へ糖を付加する反応を触媒する。通常、受 容体に対しても供与体に対しても基質特異性が高い。糖転移酵 素はその塩基配列の相同性に基づいて、機能的な遺伝子ファミ リーに分類することができ、それは供与体の特異性、受容体の 特異性、結合様式の特異性などの、酵素の特異性を反映する。 


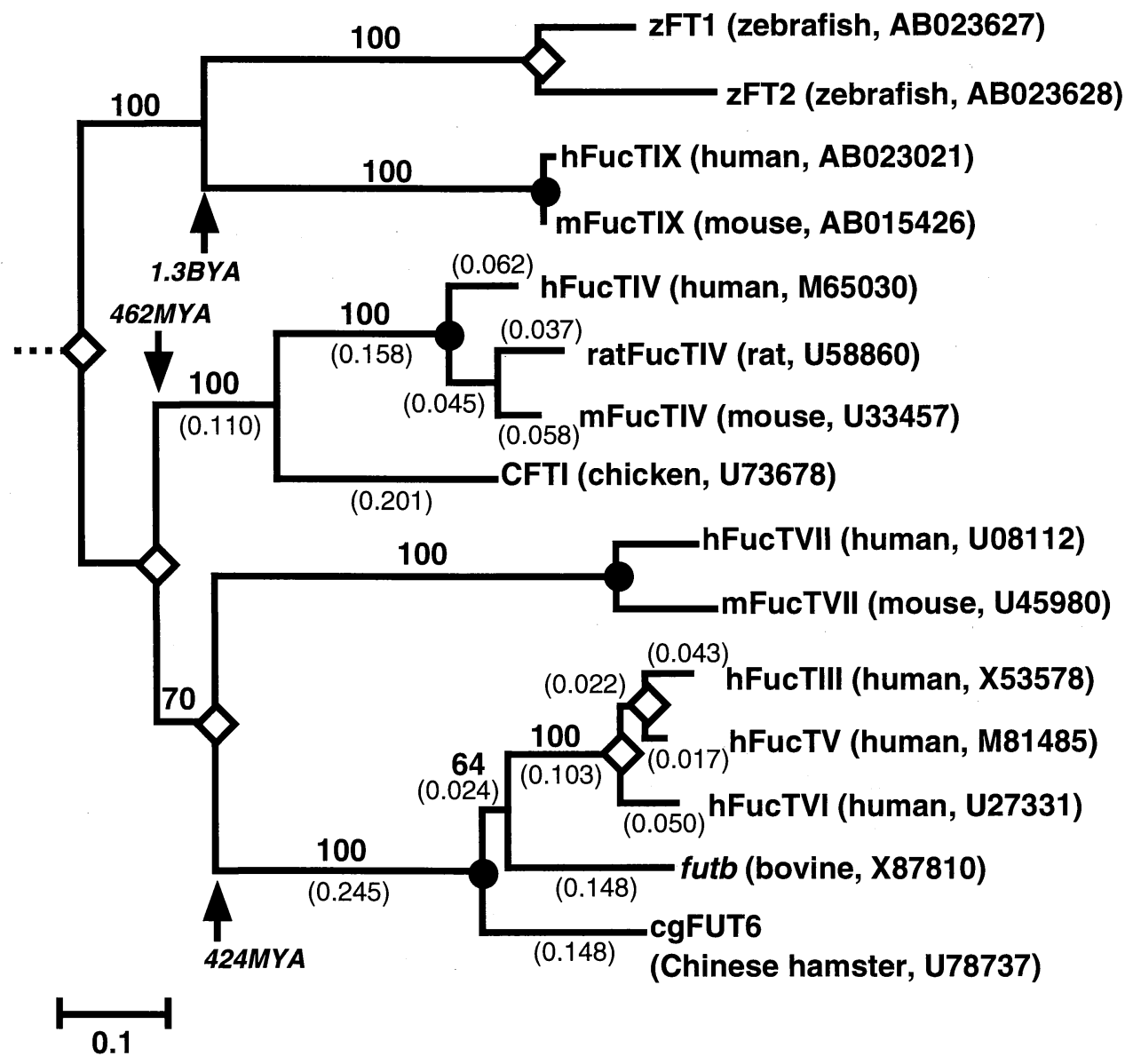

Fig. 1. The phylogenetic tree of $\alpha 1,3$ Fucosyltransferase. The root was determined previously (assuming that $C$. elegans were located as outgroups) and indicated with a dotted line. Gene duplication within the $\alpha 1,3$ FucT family occurred before the emergence of Pisces, after the divergence between vertebrates and invertebrates. The number in brackets refers to the branch length (amino acid substitution/site). The branch lengths indicate evolutionary distances between different genes. Bootstrap values are shown on each branch. Open diamond marks indicate the gene duplication and solid circles indicate the speciation of human and rodents.

acceptor. We conducted molecular evolutionary analyses on 55 glycosyltransferase genes and they constitute at least 15 phylogenetic trees (1). This was the first example of an analysis of such a large number of glycosyltransferase genes through molecular evolutionary methods. We have indicated the phylogenetic tree of $\alpha 1,3$ Fucosyltransferase gene family (Fig. 1) as an example and will explain how we performed molecular evolutionary analyses.

$\alpha 1,3$ Fucosyltransferase $(\alpha 1,3 \mathrm{FucT})$ transfers a fucose (Fuc) from guanosine diphosphate-fucose (GDP-Fuc) to $\mathrm{N}$ acetylglucosamine (GlcNAc) of a type 2 chain, Gal 31 , 4 GlcNAc$\mathrm{R}$, with $\alpha 1,3$-linkage. The genes encoding $\alpha 1,3$ FucT form a $\alpha 1,3$ FucT family. So far, the human genes encoding six $\alpha 1,3$ FucTs (FucTIII, IV, V, VI, VII and IX) have been cloned.

Fig. 1 shows that the inferred tree of the $\alpha 1,3$ FucT fam-
我々は55種類の糖転移酵素遺伝子に対して解析を行い、少なく とも15種類の系統樹を構成した。これだけの多種類の糖転移酵 素遺伝子にわたって、一貫した進化学的解析を行ったのは本報 が初めての試みであった。 $\alpha 1,3$ フコース転移酵素遺伝子ファミ リーの系統樹を図 1 に例として示し、分子進化学的解析の道筋 を説明する。

$\alpha 1,3$ フコース転移酔素は 2 型糖鎖のN-アセチルグルコサミ ンにGDP-Fucからフコースを $\alpha 1,3$ 結合で転移する活性を持つ。 $\alpha 1,3$ フコース転移酵素をコードする遺伝子は、遺伝子ファミ リーを形成している。現在までに、ヒトゲノムでは6種の $\alpha 1,3$ フコース転移酵素(FucTIII、IV、V、VI、VII、IX)が単離されて いる。

図 1から明らかなように、 $\alpha 1,3$ フコース転移酵素ファミ 


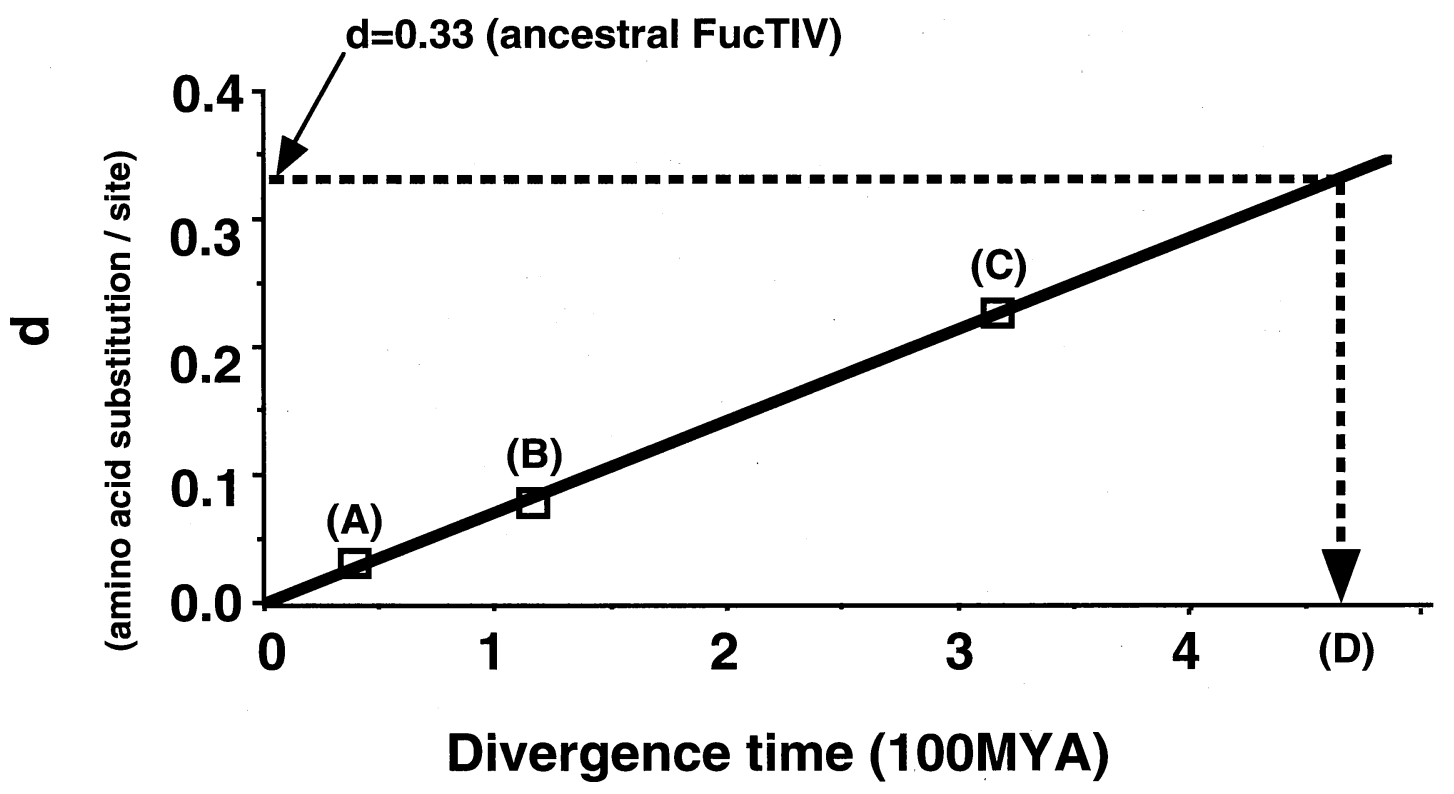

Fig. 2 Estimation of evolutionary rate and divergence time. The divergence time of roots for each gene group is estimated by using regression through the origin. For example, it indicates comparisons between amino acid substitutions and divergence times from a cluster of the FucTIV gene. The cluster of the FucTIV gene has four OTUs (human, mouse, rat and chicken). The divergence time between mouse and rat was 41MYA (A), human and rodents was 112MYA (B), human and chicken was 310MYA(C). The time (D) of the root of FucTIV gene cluster was calculated to correspond to about 462MYA.

ily revealed four separate subfamilies: 1: FucTIX (human, mouse, and zebrafish), 2: FucTIV (human, mouse, rat, and chick), 3: FucTVII (human and mouse), and 4: FucTVI (three human FucTs, hamster cgFUT6, and bovine futb). The root determined previously (2) was indicated as a dotted line. Nishihara et al. (3) determined in detail the characterization of fucosyltransferase activity for polylactosamine units. FucTIX exhibited a completely different specificity of Fuc transfer to GlcNAc residues from the other four $\alpha 1,3$ FucTs. FucTIX preferentially fucosylates the distal GlcNAc residue of polylactosamine chain, while the other four FucT members, FucTIII, FucTIV, FucTV and FucTVI, preferentially fucosylated the inner GlcNAc residue. FucTVII could not transfer a fucose to an acceptor, which is non-sialylated. The enzyme activities are very compatible with the phylogenetic tree of Fig. 1.

Then we estimated the divergence time of the FucT gene groups. More than three OTU (operational taxonomic unit) allow us the estimation of the divergence time on the assumption that the evolutionary rate is constant. Fig. 2 indicates the relation between amino acid substitutions (d) and divergence times $(t)$. Divergence times of roots of each gene groups are estimated by using the regression through origin. As for example, the FucTIV gene cluster has four OTUs, human, mouse, rat and chicken. The divergence time between mouse and rat was 41MYA (A), that between human and rodents was 112MYA (B) and that between human and chicken was 310MYA (C),
リーは以下の4つのサブグループに分かれている。1：FucTIXの サブグループ(ヒト、マウス、ゼブラフィッシュ)、2：FucTIVの サブグループ(ヒト、マウス、ラット、ニワトリ)、3：FucTVIIの サブグループ(ヒト、マウス)、 4 ：FucTVIのサブグループ(3つの ヒトFucT、ハムスター、ウシ)。系統樹の根は点線で示した(2)。 西原ら(3)はポリラクトサミンユニットに対するフコース転移酵 素活性の相違を詳細に調べ、FucTIXが他のフコース転移酵素群 のフコース転移酵素とは全く基質特異性が異なることを明らか にした。FucTIXはポリラクトサミンの非還元末端側にフコース を転移しやすい。一方、FucTVIIをのぞく他のフコース転移酵素 群の酵素は、むしろ内側のN-アセチルグルコサミンにフコース を転移しやすい。FucTVIIはシアル酸を含まない基質には反応し ない。これらの酵素の基質特異性の細かな相違点は、系統樹の 分岐の様子と良く一致していた。

フコース転移酵素遺伝子群の分岐年代を推定した。3つ以上 のOTUが存在すれば、進化速度を一定と仮定して分岐年代が推 定できる。図 2 に示すように、アミノ酸置換数 (d) と分岐年代 $(\mathrm{t})$ とを比較し、分岐年代をゼロを通る回帰直線より求めた。例え ば、FucTIV遺伝子群は4つのOTUを持つ(ヒト、マウス、ラッ ト、ニワトリ)。マウスとラットの分岐年代は41MYA(A)、ヒト と踾歯類の分岐年代は $112 \mathrm{MYA}(\mathrm{B}) 、$ ヒトと鳥類の分岐年代が 310MYA(C)と推定されている(4)。FucTIV遺伝子群の根本は 


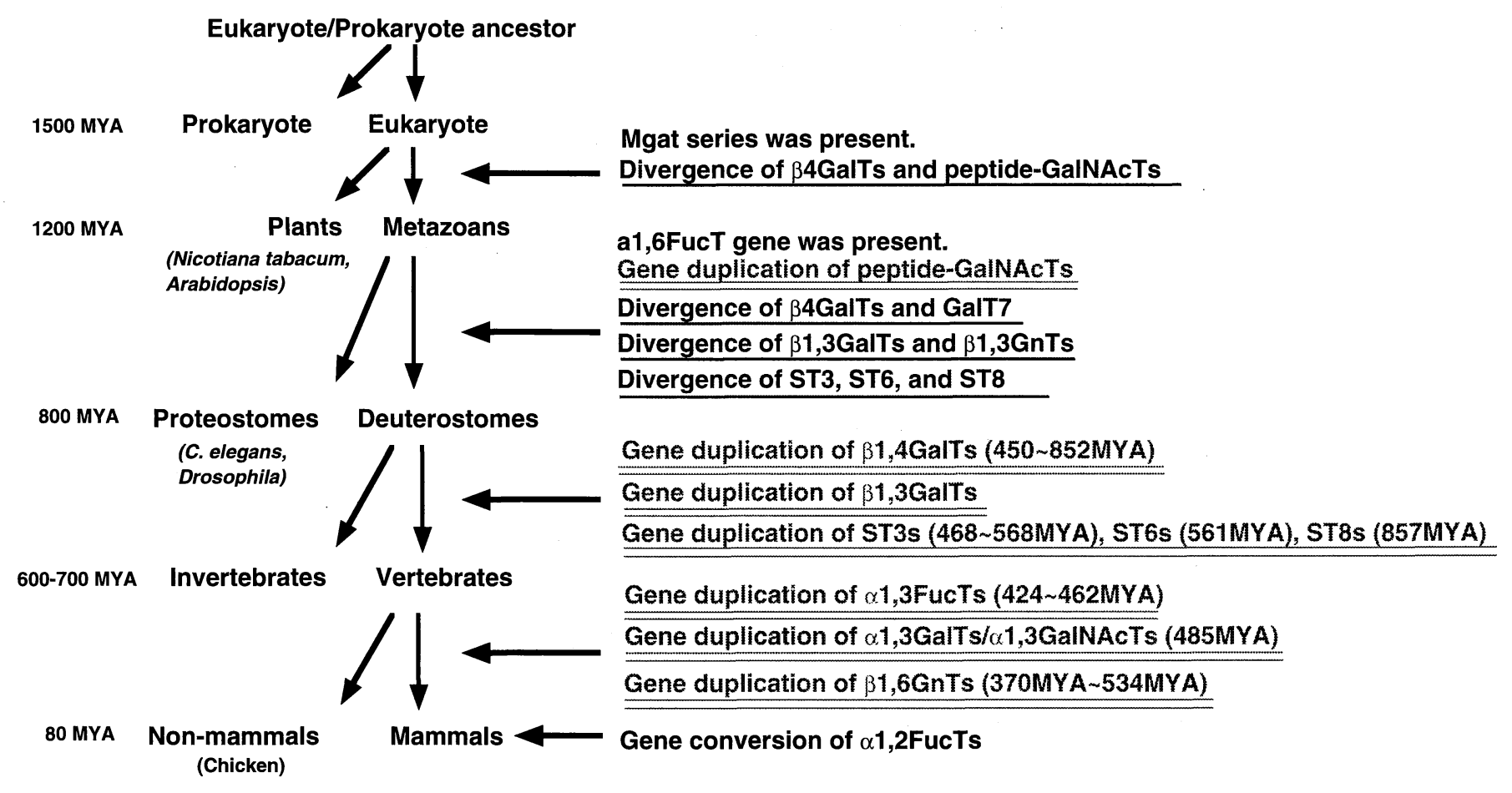

Divergence of inter-gene family Gene duplication of Intra-gene family.

Fig. 3. Evolutionary events of glycosyltransferase genes. We summarized the divergence time of each branch root. It suggests that the gene duplication of intra-gene family was concentrated around the early period of vertebrate lineage.

(4). The time (t) of the root of the FucTIV gene cluster was assumed to correspond to 462MYA (D). Likewise, times of the root of FucTVII, and FucTIX were assumed to be 424MYA, and 1.3BYA, respectively. The evolutionary rate of the FucTIX gene was very low, thus the divergence time of the root of FucTIX was over estimated. Therefor gene duplication within the $\alpha 1,3$ FucT family occurred before emergence of the Pisces, after divergence between Vertebrates and Invertebrates.

We performed molecular evolutionary analyses on 55 glycosyltransferase genes and constructed 15 phylogenetic trees (1). Then we estimated the divergence time of each branch root as summarized in Fig. 3. The result showed that gene duplication of the intra-gene family is concentrated around the early period of vertebrate lineage. Prior to gene duplication of the intra-gene family, gene duplication of the inter-gene family seems to have occurred.

\section{B. Chromosomal Localization of Glycosyltransferase Genes}

In vertebrate genomes it is often found that the homologues of a cluster of genes form another cluster on a different chromosome. Recent investigations have demonstrated that two genome-duplication events occurred; one close to the origin of
462MYAに相当した。同様にして、FucTVII、FucTIXの分岐年代 もそれぞれ424MYA、1.3BYAと推定された。FucTIX遺伝子の進 化速度が非常に遅いため、分岐年代は大幅に古い年代にシフト して推定された。 $\alpha 1,3$ フコース転移酵素遺伝子ファミリー内の 遺伝子重複は、おそらく、魚類の出現前加ら脊椎動物 - 無脊椎 動物の分岐後にかけて起こったものと推定される。

我々は55種類の糖転移酵素遺伝子を解析して、15種類の系 統樹を作成した(1)。各系統樹より各遺伝子の分岐年代を推定し て、図3にまとめた。この結果より、遺伝子ファミリー内にお ける遺伝子重複が脊椎動物の分岐後に集まっていることが明ら かになった。また、遺伝子ファミリー内の遺伝子重複が起こる 前に、遺伝子ファミリー間の遺伝子重複が起こったと考えられ た。

\section{B. 糖転移酵素遺伝子の染色体位置}

脊椎動物のゲノムにおいて、ある遺伝子群に相同な他のク ラスターが、異なった染色体上にも見いだされることがしばし ばある。近年の研究から、脊椎動物の出現付近と顎口類の出現 
Table I. Chromosomal location of glycosyltransferase genes.

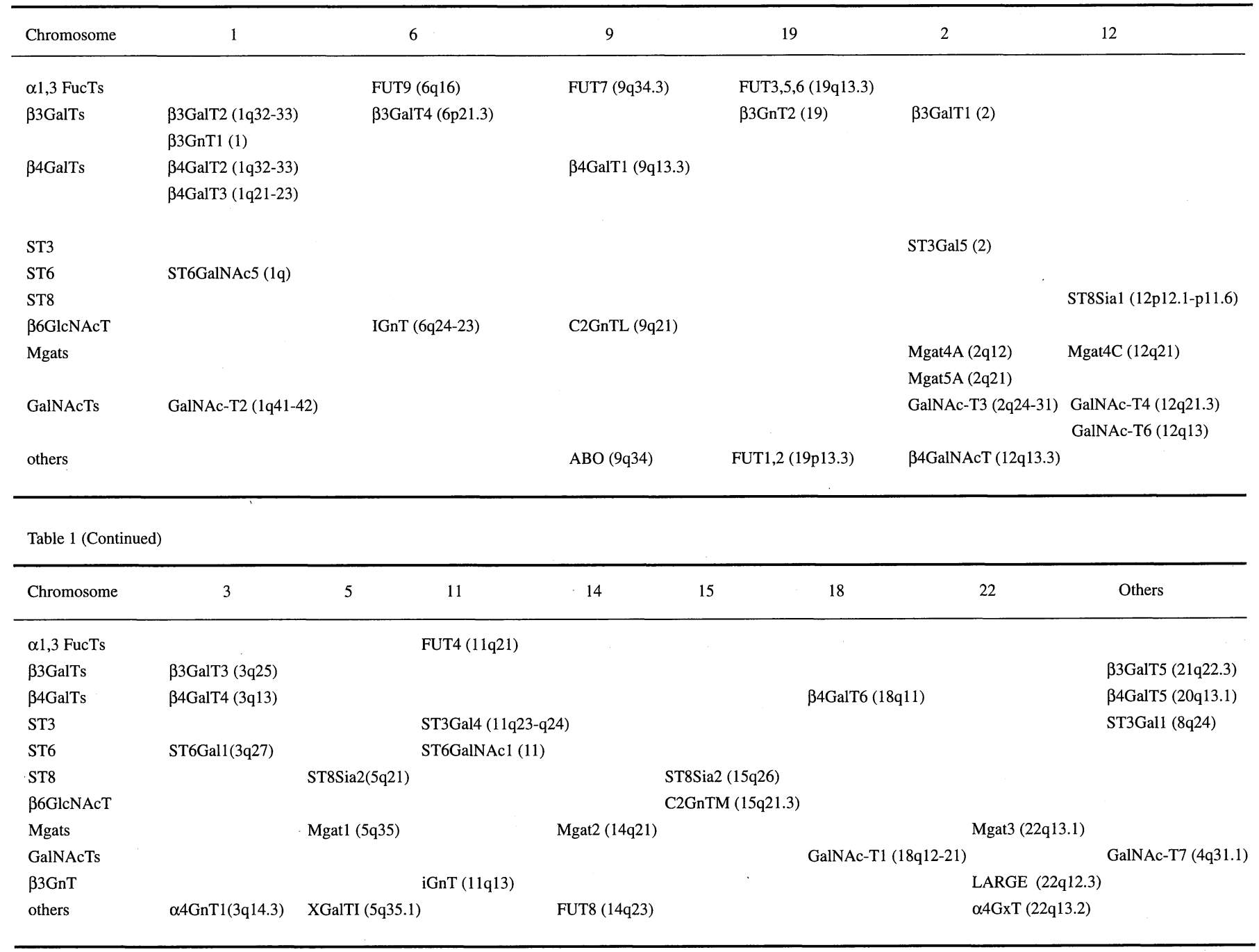

the vertebrates and the second close to the origin of the gnathostomes (5). For example, the MHC paralogous regions were detected on chromosomes $1,6,9$, and 19 . Genes of the Hox cluster are mapped to chromosomes 2, 7, 12, and 17 (6). These four regions may also be the remnant of the four homologous segments that arose from the genome tetraploidization. We detected that glycosyltransferase genes also show "homologous clusters" such as the MHC region and Hox cluster. We listed up the chromosomal location of glycosyltransferases in Table I. The first line indicates chromosomal number. First, we picked up the genes of glycosyltransferases on chromosomal regions corresponding to MHC clusters (Chr. 1, 6, 9, and 19) and Hox clusters (Chr. 2, 7, 12, and 17). Five $\alpha 1,3 F u c T$ genes, FucTIII, FucTV, FucTVI, FucTVII, and FucTIX were placed in chromosomes 6, 9, and 19, while FucTIV was placed in chromosome 11. Four $\beta 3$ GalT genes were placed in chromosomes 1,6 , and 19 , while two $\beta 3$ GalT genes were placed in chromosome 3 , and 21 . We
付近との2回のゲノム重複が起こったことが示されている(5)。例 えば、6番染色体のMHCの相同な領域が染色体の 1、9、19番に 見いだされる。Hoxクラスターは2、7、12、17番染色体上に見 いだされる(6)。これら4カ所の領域は、ゲノムの4倍体化(2回の ゲノム重複)の痕跡として残っているのだろう。我々はMHC領域 やHoxクラスターと同様に、糖転移酵素が「ホモロガスクラス ター」を形成していることを見い出した。表 I に糖転移酵素遺 伝子の染色体位置を示した。最上段は、染色体番号である。初 めに、MHC領域のホモロガスクラスターの存在する染色体(1、 6、9、19番染色体)と、Hoxクラスターの存在する染色体 $(2 、 7 、$ 12、17番染色体)に着目した。 $\alpha 1,3$ フコース転移酵素遺伝子群 に属する酵素においては、6、9、19番の染色体上に 5 つの遺伝 子が存在するが、FucTIVは、両クラスターに属さない11番染色 体上に存在した。 $\beta 1,3$ ガラクトース転移酵素遺伝子群では、 1、6、19番染色体に4つの遺伝子が位置しており、そ扎以外には 3番染色体、21番染色体に一つずつ存在する。この様にして順 
Trends in Glycoscience and Glycotechnology Vol.13 No.70 (March 2001) pp.147-155

also placed $\beta 4 \mathrm{GalTs}$, sialyltransferases, GlcNAcTs, GalNAcTs, and others. The Hox type grouping of chromosomes 2, 7,12, and 17 did not include many glycosyltransferase genes, only GlcNAcTs and GalNAcTs were concentrated on chromosome 2 and 12.

One would expect that if the subset of the genome was duplicated, all the phylogenetic trees should indicate the same topology. The phylogenetic trees of the glycosyltransferase gene did not clearly indicate such an evolutionary history. For example, the phylogenetic tree of $\alpha 1,3$ FucT (Fig. 1) indicates that the FucTIX (Chr. 6) diverged first, and then FucTIV (Chr. 11) diverged from the group, FucTIII (Chr. 19) and FucTVII (Chr. 9 ), by gene duplication. But the phylogenetic tree of $\beta 3 \mathrm{GalT}$ (not shown) indicates that $\beta 3 \mathrm{GalT} 2(\mathrm{Chr}$. 1) and $\beta 3 \mathrm{GalT} 3$ (Chr. 3) are clustered, while b3GalT4 (Chr. 6) diverged first. This is not compatible with the hypothesis of homologous cluster. But there is no reason to reject the hypothesis of the homologous cluster, because no one knows which gene is the correct homologous gene with each other. For example, tandem duplications occurred in ancient chromosomes (ex. gene A and gene A' on an ancestral chromosome). It had been maintained for a long time. During the periods, many of the tandem duplicates were expected to occur to evolve different functions. Gene loss can be expected only when further duplications (or genome duplication) occur (ex. A+A' on Chr.1 and A+A' on Chr.3). Gene loss might occur randomly (ex. A' on Chr.1 and A on Chr.3 had disappeared). So the gene cluster of the phylogenetic tree is inconsistent with each other (7). Anyway, as shown in Table I, we can predict the existence of novel cluster regions in chromosomes, $3,5,11,14,15,18$, and 22 . It is possible that further glycosyltransferase genes may be found and mapped on this novel group. The timings of gene duplication that were estimated by molecular evolutionary analyses (Fig. 3) were compatible with the period of genome duplication.

\section{Estimation of Evolutionary Rates and Divergence Time}

We calculated the numbers of synonymous $\left(d_{s}\right)$ and nonsynonymous $\left(\mathrm{d}_{\mathrm{N}}\right)$ nucleotide substitutions between human and a rodent (mouse, chinese hamster, or rat) for each glycosyltransferase gene (Fig. 4). Evolutionary rate ( $\lambda$ ) is relative to nucleotide substitutions. First we expected that the evolutionary rate depended on the glycosyltransferase family. In other words, we expected the evolutionary rate of the enzymes which synthesize core structure, to be slow and the evolutionary rate of terminal sugar-transferase, such as fucosyltransferases and a part of sialyltransferases, may be high. Contrary to this expectation, glycosyltransferase genes have a variety of evolutionary rates in each family. It is interesting that the gene FucTIX, which indicated the lowest rate, and the gene FucTIII and FucTVI, which indicated the highest $d_{N}$ values, belong to the same glycosyltransferase family. It is emphasized that the num-
に、 $\beta 1,4$ ガラクトース転移酵素遺伝子群、シアル酸転移酵素 群、各種のGlcNAc転移酵素群、GalNAc 転移酵素群に属する遺 伝子の染色体位置を列挙した。Hoxホモロガスクラスターの のっている染色体 $(2 、 7 、 12 、 17)$ に存在する遺伝子は少なく、2 番、12番染色体にGlcNAc転移酵素とGalNAc 転移酵素が見いた されたのみである。

もし、ゲノム重複で遺伝子が増えたのならば、全ての系統 樹が同じトポロジーを示すと期待できるであろう。しかし、実 際には、糖転移酵素遺伝子の系統樹はそのような系統関係を示 していない。例えば、 $\alpha 1,3$ フコース転移酵素遺伝子の系統樹(図 1)は、FucTIX(6番染色体)が一番初めに分岐し、次にFucTIV(11 番)、FucTVI グループ(19番)とFucTVII(9番)と順に遺伝子重複が 起こったことを示している。また、本稿には示さなかったが、 $\beta 1,3$ ガラクトース転移酵素遺伝子では、 $\beta 1,3 \mathrm{GalT} 4(6$ 番)が一番 初めに分岐し、 $\beta 1$ 1,3GalT2(1番)と $\beta$ 1,3GalT3(3番)がクラスター を形成している。これらの結果は、ゲノムの重複で遺伝子が増 えたとする本総説に示した説と矛盾するように考えられる。し かし、とはいえ、その説を棄却してしまうのはまだ時期早しょ うである。なぜなら、誰にも、どの遺伝子同志が本来の相同遺 伝子対なのか、分からないからだ。例えば、過去において、あ る祖先染色体上で並列に遺伝子重複が起きたとする(遺伝子Aと $\mathrm{A}^{\prime}$ )。長い時間の経過の中で、それらの遺伝子は機能的に異なっ た進化を遂げるだろう。その後、さらなる遺伝子重複(ゲノム重 複)(例えば、Chr.1は A+A'、Chr.3はA+A')が起き、それに伴っ て、遺伝子の欠損が引き起こされる場合もある。その際、欠損 の仕方はランダムである(例えばChr.1はA'、Chr.3はAが欠損す る)。よく似た、しかし実際には祖先遺伝子の異なる遺伝子がラ ンダムに残るので(Chr.1のAとChr.3のA')、系統樹は各遺伝子ご とに違うトポロジーを持つようになる(7)。いずれにしても、 Table I から、3、5、11、14、15、18、22番染色体に新たなホモ ロガスクラスターがある可能性が示唆される。これらのホモロ ガスクラスターのある位置にさらに糖転移酵素遺伝子が見いだ される可能性がある。解析を行って見積もった遺伝子の分岐年 代を図 3 に示したが、これはゲノム重複の時期と一致した。

\section{C. 糖転移酵素遺伝子の進化速度と分岐年代}

糖転移酵素遺伝子のヒトと毒歯類(マウス、チャイニーズハ ムスター、あるいは、ラット)の配列を比較して、同義置換数と 非同義置換数を計算した(図4)。進化速度はこれら塩基置換数に 比例する。最初我々は、進化速度が糖転移酵素の遺伝子ファミ リーに依存するであろうと考えた。換言すると、還元末端側の 糖鎖を合成する糖転移醩素の進化速度は遅く、非還元末端側の 糖鎖を合成する糖転移酵素(例えば、フコース転移酵素や一部の シアル酸転移酵素など)の進化速度はおそらく早いと予想してい た。予想に反して、糖転移酵素遺伝子の進化速度は、遺伝子 ファミリー内でばらつきが認められた。同じフコース転移酵素 遺伝子ファミリーでも、FucTIXは最も進化速度が遅く、一方、 FucTIII や FucTIVIは最も $\mathrm{d}_{\mathrm{N}}$ 值の高い進化速度の早いグループに 属する。特筆すべき事は、FucTXI、 $\beta 3$ GalT1, そしてGalNAcT7 の $\mathrm{d}_{\mathrm{s}}$ 值がアクチンやヒストンなどの值と同じ程度低い值を示す 

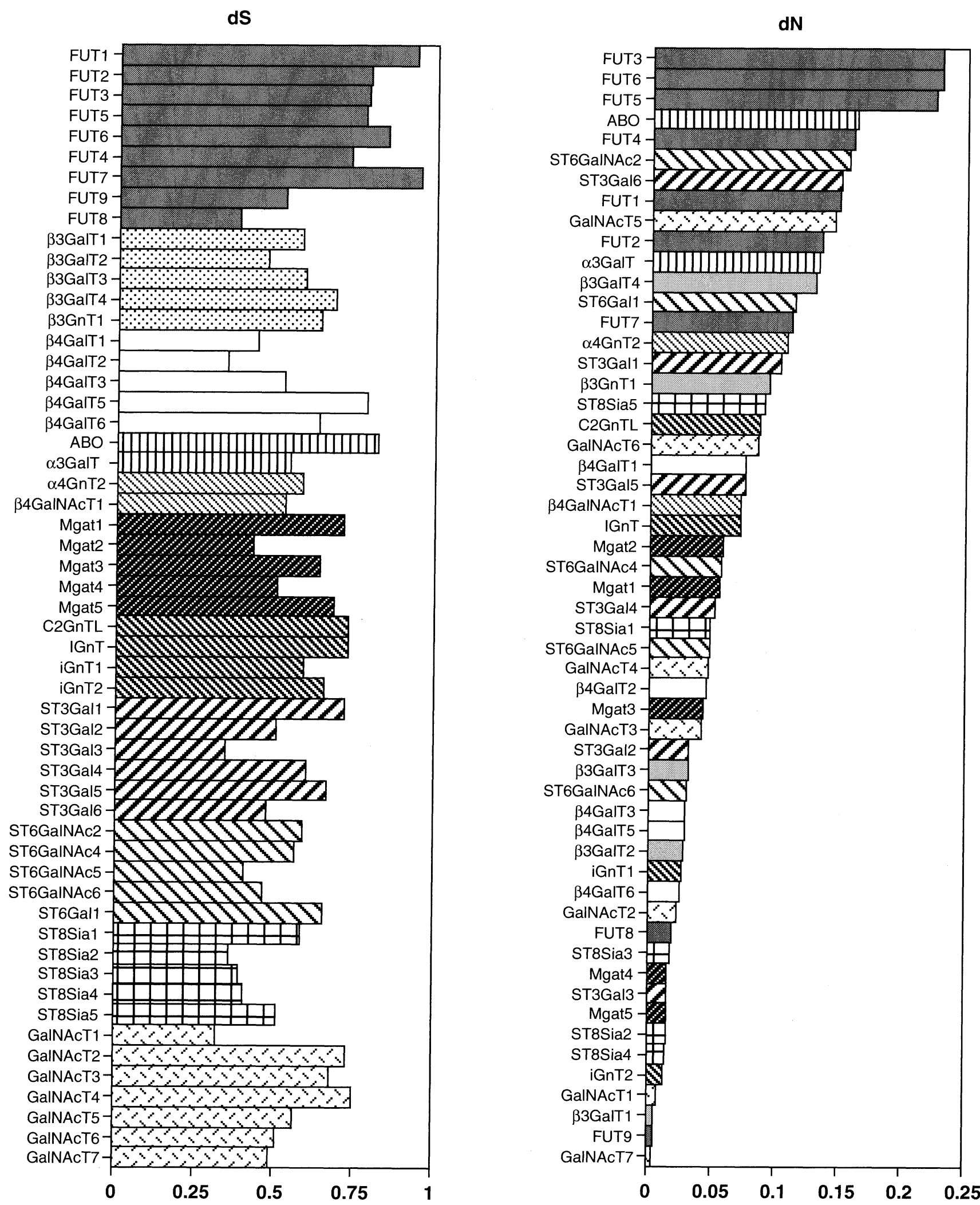

Fig. 4 Comparison of the number of synonymous nucleotide substitutions and nonsynonymous nucleotide substitutions for glycosyltransferases between human and rodents. Each of the glycosyltransferase gene families was distinguished by using different patterns in the columns (see Fig. 4A). In A, the number of synonymous nucleotide substitutions $\left(\mathrm{d}_{s}\right)$ are indicated for each glycosyltransferase gene family. In $\mathrm{B}$, nonsynonymous nucleotide substitutions $\left(\mathrm{d}_{\mathrm{N}}\right)$ are indicated in value order. 
Table II. Timing of gene duplications.

\begin{tabular}{|c|c|c|c|c|c|c|c|}
\hline & \multicolumn{7}{|c|}{ Divergence time } \\
\hline & $\begin{array}{l}\text { Invertebrate } \\
\text { counterpart }\end{array}$ & $\begin{array}{l}\sim 1.5 B Y A \\
\text { Eukaryote/ } \\
\text { Prokaryote }\end{array}$ & $\begin{array}{l}\sim 1.2 B Y A \\
\text { Plants / } \\
\text { Metazoans }\end{array}$ & $\begin{array}{l}\text { 800MYA } \\
\text { Proteostomes / } \\
\text { Duoterostomes }\end{array}$ & $\begin{array}{l}\text { 600-700MYA } \\
\text { Invertebrates/ } \\
\text { Vertebrates }\end{array}$ & $\begin{array}{l}\text { Vertebrate } \\
\text { linage }\end{array}$ & $\begin{array}{l}\quad \text { 80MYA } \\
\text { Non-mammalian } \\
\text { Mammalian }\end{array}$ \\
\hline$\alpha 1,2$ FucT & - & & & & & & + \\
\hline$\alpha 1,3$ FucT & + & & + & & & $+(424 \sim 462)$ & \\
\hline$\alpha 1,6$ FucT & + & + & & & & & \\
\hline$\beta 4 \mathrm{GalT}$ & + & $(*)$ & & $+(817)$ & $+(782)$ & $+(463 \sim 563)$ & \\
\hline$\beta 3 \mathrm{GalT}$ & + & & & & + & + & \\
\hline$\alpha 1,3 \mathrm{GalT}$ & - & & & & & $+(485)$ & \\
\hline ST3 & - & & & & & $+(468 \sim 568)$ & \\
\hline ST6 & - & & $+(1.9 \mathrm{~B})$ & & & $+(561)$ & \\
\hline ST8 & - & & $+(1.9 \mathrm{~B} \sim 2.1 \mathrm{~B})$ & $+(857)$ & & & \\
\hline$\beta 6 \mathrm{GnT}$ & + & & & $+(\sim 900)$ & & $+(\sim 500)$ & \\
\hline Mgat1 & + & & $+(1.1 \mathrm{~B})$ & & & & \\
\hline Mgat2 & + & & + & & & & \\
\hline Mgat3 & + & + & & & & & \\
\hline Mgat4 & + & & + & & & & \\
\hline Mgat5 & + & & & + & & & \\
\hline GalNAcT & + & $(*)$ & + & & & & \\
\hline
\end{tabular}

(*): GalNAcT have traces of similarity with the $\beta 4$ GalT motif. There is the possibility that GalNAcT, $\beta 1,4$ GalT and XGalT diverged from the same ancestral gene before the emergence of Deuterostomes.

bers of $d_{N}$ values of FucTIX, b3GalT1 and GalNAcT7 genes are as low as those of histone and actin genes (8).

The phylogenetic analyses revealed that the glycosyltransferase increases their genes by gene duplication or chromosomal duplication. As a result, glycosyltransferases have a variety of evolutionary rates; some are very conserved, others are less conserved. We estimated the numbers of ancestral genes and duplication events. We also indicate the divergence time estimated by the phylogenetic tree (Table II). We also showed whether invertebrate counterparts exist or not. $\alpha 1,2 \mathrm{FucT}$ ( $H$ and $\mathrm{Se}$ gene), $\alpha 1,3 \mathrm{GalT} / \mathrm{GalNAcT}$ (ABO), and STs do not have invertebrate counterparts. It is interesting that $\alpha 1,2 \mathrm{FucT}$ and $\alpha 1,3 \mathrm{GalT} / \mathrm{GalNAcT}$ are involved in the synthesis of a blood group antigen. In other words, they can act at the "postcore" (terminal) position of glycan. Sialic acids are also found on the terminal or subterminal position. It suggests that these genes appeared after the divergence of vertebrates and invertebrates, or the rapid evolutionary rate prevents detection by homology search. As shown in Fig. 3, the gene duplication of the intragene family was concentrated around the early period of vertebrate lineage. It seems reasonable to suppose that the glycosyltransferase genes increased by chromosomal duplication in vertebrate lineage, after divergence of Duoterostomes and Proteostomes.
事である(8)。

系統樹の解析より、糖転移酵素遺伝子は遺伝子重複、ある いは、ゲノム重複により、その数を増やしていった。そして、 糖転移酵素遺伝子は様々な進化速度を持つようになった。ある 遺伝子は非常に保存され、またある遺伝子はあまり保存されな い。表 IIに、(1)過去に起こった遺伝子重複の見積り、(2)糖転移 酵素遺伝子ファミリーおける無脊椎動物の対応する遺伝子の有 無、(3)遺伝子ファミリー内の遺伝子の分岐年代を示した。 $\alpha 1,2$ フコース転移酵素 ( $H$ and Se gene)、 $\alpha 1,3$ ガラクトース・N-アセ チルガラクトサミン転移酵素 (ABO enzyme)、そして、シアル 酸転移酵素は、無脊椎動物に対応する遺伝子が見いだされな かった。 $\alpha 1,2$ フコース転移醳素と $\alpha 1,3$ ガラクトース・N-アセ チルガラクトサミン転移酵素は、血液型抗原合成に関わる酵素 である。これらは、また、糖鎖の末端構造合成に働く糖転移酵 素群に属する。シアル酸も、末端構造に見い出される。これら の遺伝子は、脊椎動物と無脊椎動物の分岐後から出現したの か、あるいは、遺伝子の進化速度が早まり、相同性検索では検 出することが不可能になってしまったのだろう。図 3 にも示し たように、遺伝子ファミリー内での遺伝子重複は脊椎動物系列 の最初の年代に集中して起こった。その後 2 回起ったゲノム重 複で、糖転移酵素遺伝子がその数を増やした、という仮説は筋 が通っていると考えられる。 


\section{References}

1. Kaneko, M., Nishihara S., Kitano T., Narimatsu, H., and Saitou, N. (2001) (in preparation)

2. Kaneko, M., Kudo, T., Iwasaki, H., Ikehara, Y., Nishihara, S., Nakagawa, S., Sasaki, K., Shiina, T., Inoko, H., Saitou, N., and Narimatsu, H. (1999) FEBS Letters 452, 237-242

3. Nishihara, S., Iwasaki, H., Kaneko, M., Tawada, A., Ito, M., and Narimatsu, H. (1999) FEBS Letters 462, 289-294

4. Kumar, S., Hedges, S.B. (1998) Nature 392, 317-920

5. Kasahara, M., Nakaya, J., Satta, Y., and Takahata, N. (1997) Trend in Genetics 13, 90-92

6. Bailey, W.J., Kim, J., Wagner, G.P., and Ruddle, F.H. (1997) Mol. Biol. Evol. 14, 843-853

7. Smith, N., G.C., Knight, R., and Hurst, L. (1999) Bio Essays 21, 697-703

8. Li, W.H., Wu, C.I., and Luo, C.C. (1985) Mol. Biol. Evol. 2, 150-174

Received on February 9, 2001, accepted on March 28, 2001

\section{Profile of the Author}

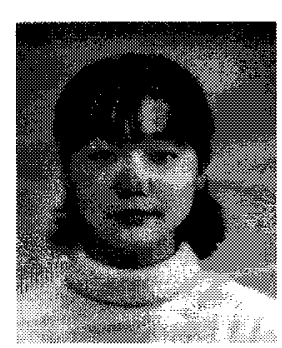

\section{Mika Kaneko}

She obtained a PhD at Department of Genetics, School of Life Science, Graduate University for Advanced Studies in 1999. The $\mathrm{PhD}$ thesis introduced in this article was carried out at the Laboratory of Evolutionary Genetics, National Institute of Genetics under the supervision of Dr. Saitou, N. Ms. Kaneko now works at the Department of Forensic Medicine, Yamagata University School of Medicine as a research associate. 